\title{
Spatio-temporal pattern of seagrass distribution and the relation with human activities in Banten Bay
}

\author{
Muhammad Daud ${ }^{1, *}$, Tjiong Giok Pin ${ }^{1}$, and Tuty Handayani ${ }^{1}$ \\ ${ }^{1}$ Departement of Geography, Universitas Indonesia, 16424 Depok, Indonesia
}

\begin{abstract}
Seagrass meadows are important ecosystem due to their structural and functions role as a place for various nutrient cycles, feeding area, and breeding for a variety of marine species. Increased human activity in the form of shipping, sand mining, reclamation, and the development of tourism sector is reported causing disturbed seagrass condition. Therefore, spasio-temporal monitoring of the seagrass condition is important to understand the relationship between the seagrass condition and the stresses from human activity. This research was conducted to analyze the change of seagrass distribution in Banten Bay and its relation with human activity using multi temporal Landsat data from 2008 to 2018. Landsat data is processed using Depth Invariant Index method and classified using Maximum Likelihood with field data. The results of this study indicate a reduction of 74,28 ha seagrass area in the Banten Bay from 2008 to 2018 due to increased human activity.
\end{abstract}

\section{Introduction}

Seagrass is a flowering plant (Angiospermae) that lives underwater that have high salinity fluctuations. Seagrass have a rhizomes, leaves, and roots. Various marine organism makes the seagrass beds as a feeding ground, nursery ground, and spawning ground. Seagrasses also can be slowing down the wave movement, keep the stability of the sediment and as a aplace for various nutrient cycle [1]. As a true plant, seagrass can bind carbon dioxide $\left(\mathrm{CO}^{2}\right)[2]$.

Indonesian sea territory is included in the Indo Pacific tropical with the highest diversity of seagrass in the world. In Indonesian territory there are 15 types of seagrass that founded, namely Enhalus acoroides, Cymodocea rotundata, C. serrulata, Halophila decipiens, $H$. ovalis, H. minor, H. spinulosa, Haludole pinifolia, Halodule uninervis, Syringodium isoetifolium, Thalassia hemprichii, and Thalassodendron ciliatum ,Halophila sulawesii, Halophila becarii, Ruppia maritima [2, 3].

Banten Bay region has a high diversity of seagrass with a total of 7 species found on 15 species in Indonesia waters territory. The area of seagrass beds in the Banten bay in 2004 are estimated at 486.8 ha. The basis of seagrass that found in Banten Bay is mud, sand, coral reefs, and coral fragments. [4]

\footnotetext{
* Corresponding author: daudqr199@gmail.com
} 
Increased the human activity which is coastal reclamation, industry, tourism, fishery, and sand mining in the Banten Bay caused stressed to seagrass beds. According to Yunus's research [5] who states that in 1989-2002, there is 23.9 ha of seagrass area that lost in the Banten Bay. Human activities in Banten Bay will have an impact on the loss of seagrass areas that have a function as a place for various marine organisms. Therefore, periodic monitoring is needed to control the condition of seagrasses to achieve the sustainability development goals number 14, "Life Below Water".

Remote sensing can be used to mapping the seagrass area. The area that large and difficult to reach can be recorded by remote sensing in smaller time and cost less [6]. The remote sensing method have the ability to record the objects temporally, so the monitoring of seagrass can be more effective.

\section{Area of study}

Banten Bay is located in the north of Banten Province at position $5^{0} 55^{\prime}-6^{0} 5^{\prime} \mathrm{S}$ dan $106^{0}$ $5^{\prime}-106^{0} 15 \mathrm{E}$. In the north of the Banten Bay region is bordered by the Java Sea, in the east is bounded by Tanjung Pontang, and the west is bounded by Tanjung Kapo. In 2004, The area of Teluk Banten is estimated about $120 \mathrm{~km}^{2}$ with a depth did no more than 10 meters. [7].

The group of the small island can be found in the north of the Banten Bay area. The small inhabited island is called Panjang Island. The small uninhabited islands namely Pisang Island, Kubur Island, Big Pamujan Island, Small Pamujan Island, Lima Island, and the others small islands.

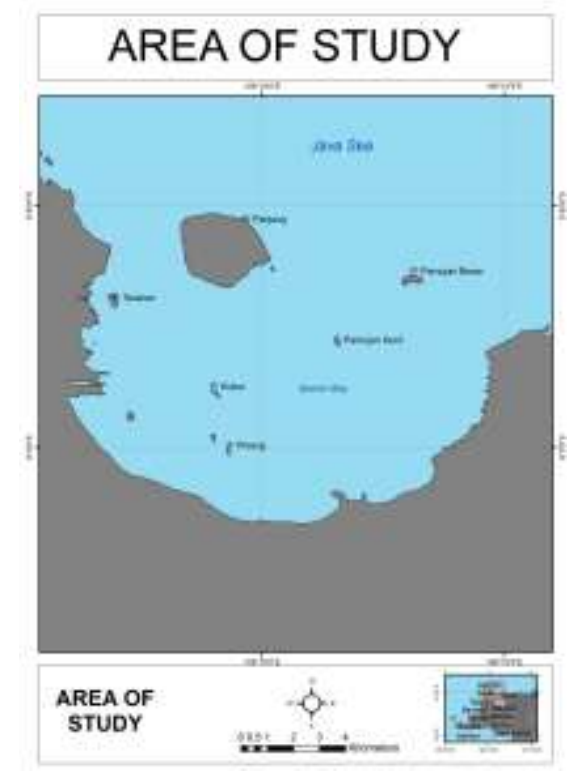

Fig. 1. Banten Bay area.

\subsection{Oceanographic condition}

According to Sakaruddin's research (2010) The temperature of the waters of Banten Bay in June ranged from $29^{\circ} \mathrm{C}-30^{\circ} \mathrm{C}$ [8]. Data collection in the field in May 2018 is not much different from previous research. The temperature at intervals between $25^{\circ} \mathrm{C}-35^{\circ} \mathrm{C}$, is the temperature which seagrass can grow normally. While the optimum temperature for 
seagrass is located at intervals of $25^{\circ} \mathrm{C}-30^{\circ} \mathrm{C}$. This indicates that seagrass can still live well at the current temperature of Banten Bay.

Salinity values measured in Banten Bay are at intervals of 28-34\% \% . Meanwhile, according to LIPI (2001) the salinity of the waters of Banten Bay in June at the intervals of $30.7-31.6 \%$ [8]. This shows that there is a difference in the results of the salinity data collection caused by the input of water from the land and the low rainfall in that month. The seagrasses can live in salinity between $10-45 \%$ [9]. This shows that salinity in Banten Bay is still relatively good for growing seagrasses. For the depths of seagrass found in this study the shallowest found at a depth of $24 \mathrm{~cm}$ and the deepest was found at a depth of 150 $\mathrm{cm}$. This indicates that seagrass in Banten Bay grows at a depth of no more than two meters is still valid [7].

\subsection{Human activities}

Human activities that must be considered for the preservation of seagrass in Banten Bay are coastal reclamation, industry, destructive fishing, marine sand mining, tourism, industrial, and domestic waste. Based on population data from the Serang Regency and Serang City Central Statistics Agency (BPS), in the last 10 years, the population in the Banten Bay region with a total of 6 sub-districts has continued to increase. In 2018 the number of residents in the sub-districts on the coast of Banten Bay totaled 348,338 people. This indicates an increase of population in $2.9 \%$ of the total population in 2008 with a total of 328,816 people.

The activity of sand mining in Banten Bay has been started since 1996 [10]. Sand mining legally since 2003 started from Lontar Village and was temporarily stopped in 2013. Sea sand mining which has lasted for more than 10 years has resulted in morphological changes as evidenced by an increase in the incidence of abrasion and accretion in the northern region of Banten [11].

The Banten Bay region has considerable tourism potential. This is due to the natural beauty of the countryside and exotic marine ecosystems such as mangrove forests, seagrass beds, corals, or nature reserves. One of the biggest potentials of Banten Bay tourism is small islands that offer the beauty of tropical island nuances and the beauty of underwater objects. The number of local and foreign tourists in Serang Regency and City in 2008 totaled 11,356,260 people. This number increased in 2013 to 12,094,227 people and decreased in 2017 with a total of 10,220,122 tourists [12].

Coastal reclamation in the western region of Banten Bay has been going on since 1999. Until 2007, the reclamation area in the western region of Banten Bay reached more than 180 ha [10]. The reclamation land is used for the purposes of developing ports, jetties and industries. This certainly will disrupt the seagrass community in the region and the surrounding small islands.

The number of industries also increased from 2008 to 2018. In 2008 the number of companies in Serang Regency and Serang City totaled 251 companies with a total of 79,265 workers. In 2013 the number of companies increased to 323 companies with a total of 128,616 workers. In 2017 the number of companies increased again to 392 companies with a total of 130,032 workers [12].

Based on data of human activity in the Banten Bay that consist of increased population, increased number of industries, sand mining, increased number of tourists, and coastal reclamation. Indicates that human activity in the Banten Bay has continued to increase in the last 10 years.

\section{Methods}




\subsection{Data collection}

This study are using the remote sensing imagery that consist with Landsat 5 TM (path/row: 123/64) that recorded in June 7, 2008, Landsat 8 OLI (path/row: 123/64) that recorded in March 10, 2013, and Sentinel-2 that recorded in June 16, 2018. To get the spectral value of seagrass effevtively, this study are only using red, green, and blue band of Landsat and Sentinel data.

The human activities that consist with the number of industry employee, number of tourist, number of population, reclamation, and sand mining are taken from stakeholders interview, relavant government agency, and literature review. The oceanographic data that consist with surface temperature, salinity, suspended materials and the depth of water are taken from the field and relavant gorenment agencies.

\subsection{Data pre-processing}

In this study, there are four steps of data processing which is atmosferic and radiometric correction, water column correction using depth invariant index (DII), classification with maximum likelihood, and accuracy assessment with confussion matrix. In the data preprocessing the imagery of Landsat and Sentinel are correctid with semu-automatic classification, After the correction, the imagery can be coreccting with the water column correction with depth invariant index (DII) in the next step [13].

\subsection{Modelling}

The results of mapping the marine ecosystem can be affected by the intensity of sunlight that decreased because of the increase of water depth [14]. Therefore, the water column correction must be used to decreasing the underwater effect using depth invariant index (DII) [15]

$$
\begin{gathered}
D I I_{i j}=\ln \left(\mathrm{L}_{\mathrm{i}}\right)-\left[\left(k_{i} / k_{j}\right) \ln \left(L_{j}\right)\right] \\
K i / k j=\alpha+\sqrt{ } \alpha^{2}+1 \\
\alpha=(\sigma \mathrm{ii}-\sigma \mathrm{jj}) / 2 \sigma \mathrm{ij}
\end{gathered}
$$

Where, $L_{i}$ and $L_{j}$ are the reflectance values of the band all $\mathrm{i}$ and $\mathrm{j}, k_{i} / k_{j}$ is ratio attenuation coefficient of the band all $i$ and $j$, бii is variance of the band $\mathrm{i}, \sigma \mathrm{jj}$ is the variance of the band $\mathrm{j}$ and $\sigma \mathrm{ij}$ is the covariance of the band.

This correction result can be seen in figure 2, where the left figure (2a) shows the original visual image in the composite RGB true view, the middle figure (2b) shows the visual of the atmospheric corrected image and the reflectance value, and the right figure (2c ) shows the visual image corrected by the water column with the DII method. In Figure 2a and figure $2 b$, there is a difference in values which can be expressed by the brightness level of the image where the atmospheric correction results show a more real and good object reflectance contrast, especially on the shallow, inner and terrestrial objects. While the initial image brightness value still doesn't look good. 


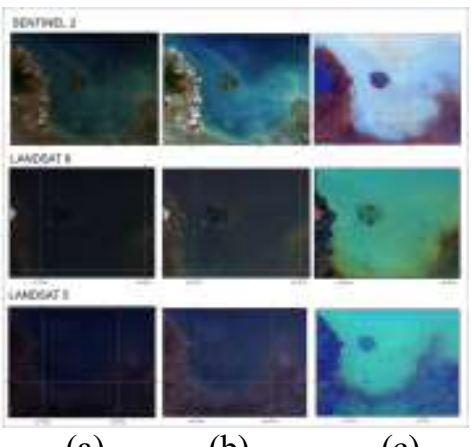

(a) (b)

(c)

Fig. 2. Image transformation results of Sentinel 2, Landsat 8, and Landsat 5 TM. (a) Original composite true image visuals (b) visual atmospheric correction results (c) visual results of water column correction with DII.

The results water column correction with the DII method indicates the contrast of objects in shallow water areas, deep waters, and land areas. This result is obtained because of the minimization of wave attenuation due to water. This result is obtained from the correction of attenuation values which can be seen in Table 1. The table shows the DII algorithm that will be applied to correct the image on the red, green, and blue bands. The algorithm will produce image values that have been corrected by the water column due to attenuation values.

Table 1. DII correction parameters on Landsat and Sentinel images.

\begin{tabular}{|c|c|c|c|c|c|c|}
\hline \multirow{2}{*}{$\begin{array}{c}\text { Band } \\
\text { Combination }\end{array}$} & \multicolumn{3}{|c|}{ Atenuation Koeficient } & \multicolumn{3}{c|}{ Atenuation koeficient ratio } \\
\cline { 2 - 7 } & $\begin{array}{c}\text { Landsat } \\
5\end{array}$ & Landsat 8 & $\begin{array}{c}\text { Sentinel } \\
2\end{array}$ & $\begin{array}{c}\text { Landsat } \\
5\end{array}$ & $\begin{array}{c}\text { Landsat } \\
8\end{array}$ & $\begin{array}{c}\text { Sentinel } \\
2\end{array}$ \\
\hline $\begin{array}{c}\text { Blue and } \\
\text { Green }\end{array}$ & $-0,2656$ & $-0,0873$ & $-0,2511$ & 0,769 & 0,9164 & 0,7798 \\
\hline Red and Blue & $-0,4169$ & $-0,2476$ & $-0,1975$ & 0,6664 & 0,7825 & 0,812 \\
\hline Red and Gren & $-1,19$ & $-0,5407$ & $-0,1179$ & 0,3643 & 0,5961 & 1,124 \\
\hline
\end{tabular}

The table also shows the attenuation coefficient and attenuation ratio coefficients in red, green, and blue bands on Landsat and Sentinel images where the higher wavelength spectrum used, the higher attenuation value gained. The deeper and wider the wavelength spectrum, the greater the attenuation of waves by water [15]. This function shows that the Lyzenga equation is linear to the depth of the waters [17].

\subsection{Image classification}

The next stage in this study is to classify the data processed with the depth variant index (DII) to obtain information on the seagrasses distribution in the Banten Bay. This classification process is carried out with the Maximum Likelihood method with the help of 100 ground truths that obtained in the field. Classification method with Maximum likelihood produces a more accurate benthic environmental map (Wicaksono, 2014). The results of this classification are divided into five classes, namely land, sand, coral, seagrass, and sea. 


\subsection{Accuracy Assessment}

Images that have been classified into five categories namely seagrass, coral reef, sand, land, and sea are tested for accuracy with the results of field data carried out on May 17 - May 20 2018. The test is done by making a confusion matrix [16].

Result Accuration $=$ Total of pure pixel all classes $/$ Total all pixel

\section{Results and discussion}

Seagrass beds in Banten Bay are agglomerate in the western region of Banten Bay and small islands. The growth pattern of seagrass beds in Teluk Banten is linear with the coastlines of small islands and on the coastline of the western region of the Bay of Banten.

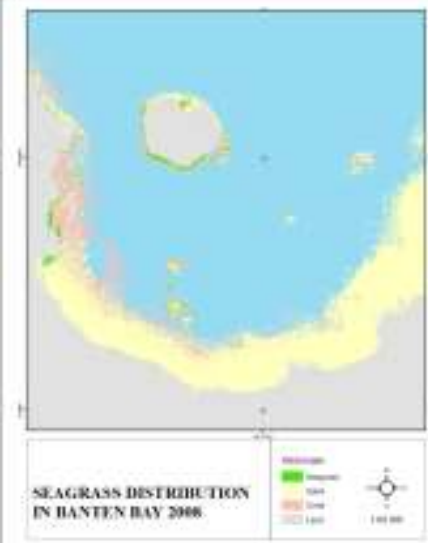

(a)

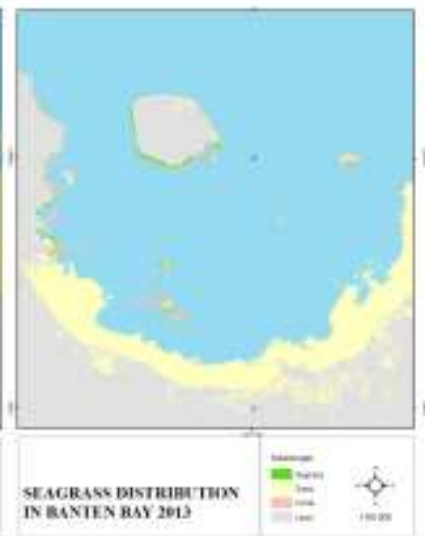

(b)

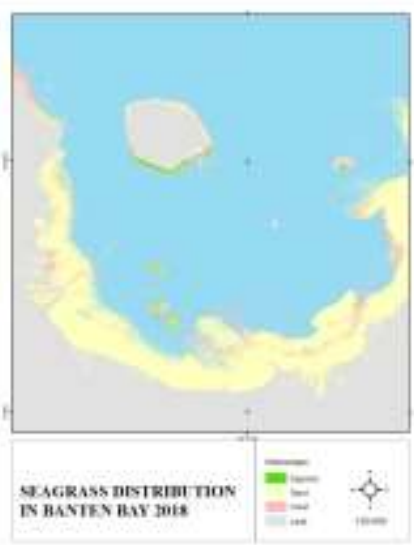

(c)

Fig. 3. Seagrass distribution map in Banten Bay (a) 2008, (b) 2013, and (c) 2018.

Seagrass area was significantly reduced in 2013 to 2018 compared to 2008 to 2013 . The area of seagrass from 2008 to 2013 are decreased by 29.23 ha and decreased by 45.05 ha in the 2013 to 2018. Seagrass beds in the Banten Bay region in 2008 were agglomerated in the west of the Banten Bay, especially in the Tanjung Kepu region and small islands include Pulau Panjang, Pamujan Besar Island, Pamujan Kecil Island, Pisang Island, and Kubur Island, and other small islands. In 2013 the area of seagrass began to decrease, especially in the western region, precisely in the area of Tanjung Kepu and its surroundings. In 2018, there was a significant decrease again in seagrass area in the western region of Banten Bay. This causes the area of seagrass beds remaining in 2018 only found in small islands.

Tabel 2. Segrass bed areas change in Banten Bay 2008-2018.

\begin{tabular}{|c|c|c|c|}
\hline \multirow{2}{*}{ Location } & \multicolumn{3}{|c|}{ Seagrass beds area (ha) } \\
\cline { 2 - 4 } & $\mathbf{2 0 0 8}$ & $\mathbf{2 0 1 3}$ & $\mathbf{2 0 1 8}$ \\
\hline $\begin{array}{c}\text { Inhabited small } \\
\text { island }\end{array}$ & 56,68 & 43,29 & 35,3 \\
\hline $\begin{array}{c}\text { Uninhabited } \\
\text { small island }\end{array}$ & 29,97 & 26,28 & 20,21 \\
\hline Main Island & 44,55 & 32,4 & 1,62 \\
\hline
\end{tabular}




\begin{tabular}{|l|c|c|c|}
\hline Total & 131,2 & 101,97 & 56,92 \\
\hline
\end{tabular}

The biggest change in seagrass area is on the main island with an area of 44.55 ha of seagrass in 2008 to 1.62 ha in 2018, followed by inhabited islands with 56.68 ha of seagrass in 2008 to 35.3 ha in 2018, and the last is on uninhabited islands of 29.97 ha in 2008 to 20.1 ha in 2018. This is due to the higher frequency of human activities on the main island compared to small inhabited islands and uninhabited small islands.

Tabel 3. Antrophogenic Stressed on segrass in Banten Bay 2008-2018.

\begin{tabular}{|c|c|c|c|}
\hline $\begin{array}{c}\text { Human } \\
\text { Activities }\end{array}$ & $\begin{array}{c}\text { Inhabited } \\
\text { Small Island }\end{array}$ & $\begin{array}{c}\text { Uninhabited } \\
\text { Small Island }\end{array}$ & Main Island \\
\hline Ship traffic & $\sqrt{ }$ & $\sqrt{ }$ & $\sqrt{ }$ \\
\hline Ship repairing & $\sqrt{ }$ & - & $\sqrt{ }$ \\
\hline Industrial & - & - & $\sqrt{ }$ \\
\hline $\begin{array}{c}\text { Coastal } \\
\text { reclamation }\end{array}$ & - & - & $\sqrt{ }$ \\
\hline Fishing & $\sqrt{ }$ & $\sqrt{ }$ & $\sqrt{ }$ \\
\hline Tourism & - & $\sqrt{ }$ & $\sqrt{ }$ \\
\hline
\end{tabular}

In table 3 we can see that the most number human activity is found on the Main Island. this is comparable to the number of seagrass srea that lost in the main island more than the other regions. Meanwhile, the lowest decrease in seagrass area in Banten Bay is found on a small uninhabited island, this is relevant to the number of human activities there. However, human activity in the small uninhabited island such as boat traffic, fishing and tourism still cause a reduction of seagrass area in this region.

\section{Conclusion}

The area of seagrass beds in the Bay of Banten in the last 10 years has been decreased from 131.2 ha in 2008 to 101.97 ha in 2013 and 56.92 ha in 2018. The largest number of seagrass areas that loss occurred in the western region of Banten Bay which is located on the main island with a lost area of 42.93 ha. Meanwhile, the smallest seagrass area lost in small islands with a total lost area of $9.87 \mathrm{ha}$. This happens because the anthropological pressure on the main island is bigger than in the small islands.

Seagrass beds in the Banten Bay are distributed linearly around the coastline on small islands with a depth of no more than 2 meters and in the good oceanographic condition that seagrass requaired. Anthropological pressure such as increased population, sand mining that has been going on since 2003, tourism development, coastal reclamation and an increase in the number of industries in the Bay of Banten are one of many main factors that reducing the areas of seagrass beds in Banten Bay. Therefore it needs further conservation efforts to maintain the sustainability of seagrass meadow.

\section{Recommendation}

Based on the results of the study, there are several recommendations to keep the sustainability of seagrass meadow. The first is the rehabilitation program for seagrass. The second is campaigning the environmental friendly tourism and industry. The third is giving 
a knowledge to the public about the importance of seagrass. The periodic monitoring of seagrass is needed too, to maintain the seagrass condition.

\section{Acknowledgements}

The author would like to thank Directorate of Research and Community Service (DRPM) Universitas Indonesia, which has supported this research in HIBAH PITTA UI year 2018 with contract number 2326/UN2.R3.1/HKP.05.00/2018.

\section{References}

1. R. C. Phillips, E. G. Menez, Seagrasses. (1988).

2. E. U Hernawan, N. D. M. Sjafrie, I. H. Supriyadi, Suyarso, M. Y. Iswari, K. Anggraini, Rahmat, Status padang lamun indonesia (2017).

3. F. Short, T. Carruthers, W. Dennison, \& M. Waycott. Global seagrass distribution and diversity: a bioregional model. Journal of Experimental Marine Biology and Ecology, 350(1-2), 3-20 (2007).

4. W. Kiswara, Kondisi Padang Lamun (seagrass) di Teluk Banten 1998-2001. (2004)

5. S. Yunus, Penilaian Dampak Aktivitas Manusia Pada Kerusakan Ekosistem Padang Lamun di Pantai Barat Teluk Banten (2008)

6. M. Kusumowidagdo, Penginderaan Jauh dan Interpretasi Citra (2007)

7. W. Kiswara, Kondisi Padang Lamun (seagrass) di Teluk Banten 1998-2001 (2004)

8. LIPI, Laporan Penelitian Wilayah Pesisir Teluk Banten Tahap Kedua. (2001)

9. C. M. Duarte, Seagrass depth limits, 40, 4 (1991)

10. Sjaifuddin, Pengelolaan lingkungan wilayah pesisir dan laut Teluk Banten Berkelanjutan (2007)

11. G. A. Rahmawan, S. Husrin, J. Prihantono, Bathymetry Changes Analysis In Serang District Waters Caused By Seabed Sand Exploitation, 9, 1 (2017)

12. Badan Pusat Statistik, Kabupaten Serang dalam angka (2018)

13. M. Hafizt, M. D. M. Manessa., N. S. Adi., B. Prayudha. Benthic Habitat Mapping by Combining Lyzenga's Optical Model and Relative Water Depth Model in Lintea Island, Southeast Sulawesi, 98, 1 (2017)

14. C. F. Chen, V. K. Lau, N. B. Chang, N. T. Son, \& S. H. Chiang, Multi-temporal change detection of seagrass beds using integrated Landsat TM/ETM+/OLI imageries in Cam Ranh Bay, Vietnam. 35, 43-54 (2016)

15. D. R. Lyzenga, Passive remote sensing techniques for mapping water depth and bottom features. Applied optics, 17, 3 (1978)

16. N. M. Short, L. M. Stuart jr, The heat capacity mapping mission (HCMM) anthology, 465 (1982)

17. M. D. M. Manessa, A. Kanno, M. Sekine, E. E. Ampou, N. Widagti, A. R. As-syakur, Shallow-water benthic identification using multispectral satellite imagery: investigation on the effects of improving noise correction method and spectral cover. 6, 5 (2014) 